ORIGINAL ARTICLE

\title{
Comparative Study of Level of Serum Uric Acid in Type 2 Diabetes Mellitus Associated with Hypertension
}

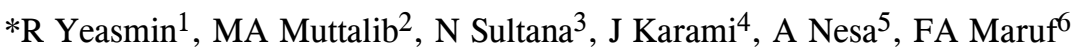

\begin{abstract}
Background: The role of uric acid in the progression of prediabetes to diabetes has been known. Serum uric acid has been shown to beassociated with cardiovascular disease, hypertension, and chronic kidney disease. However, conflicting data exist asregards the serum uric acid (UA) levels in type 2 diabetes mellitus, which are associated with risk factors andcomplications.

Material \& Methods: The present study was designed to look for any association of serum uric acid with hypertension in type 2diabetes mellitus, taking into consideration the relevant clinical, biochemical and the anthropometric data. 110 patientswith type 2 male diabetes mellitus as case and 100 healthy malecontrols were included in this study.

Results: This study shows that there were significant differences in mean of age, duration of DM, exercise time, waist hip ratio, systolic blood pressure and diastolic blood pressure within case and control but no significant differences of mean BMI was found between and control. The mean age, duration of DM, exercise time, waist hip ratio, systolic blood pressure and diastolic blood pressure and BMI were $(51.83 \pm 9.911$ years, $6.87 \pm 5.54$ years, $1.94 \pm .831$ hours, $.92 \pm .03,140 \pm 6.75 \mathrm{~mm}$ of $\mathrm{Hg}, 90 \pm 2.41 \mathrm{~mm}$ of $\mathrm{Hg}$ and $25.43 \pm 3.19 \mathrm{Kg} / \mathrm{m}^{2}$ respectively), where as in controls these were $(44.81 \pm 9.66 \mathrm{yrs}, 00$ years, $1.12 \pm .327$ hours, $.91 \pm .03,130 \pm 1.28 \mathrm{~mm}$ of $\mathrm{Hg}, 80 \pm 6.18 \mathrm{~mm}$ of $\mathrm{Hg}$ and $24.96 \pm 3.02 \mathrm{Kg} / \mathrm{m}^{2}$ respectively). This table also shows that significant differences in mean of FBS, ABF, HbA1C and S. Uric acid between case and control, but there was no significant differences of mean TG, Cholesterol, HDL and $\mathrm{LDL}$. The mean of FBS, $\mathrm{ABF}, \mathrm{HbA}_{1 \mathrm{C}}$ and $\mathrm{S}$. Uric acid among the cases were $(8.19 \pm 2.48 \mathrm{mmol} / \mathrm{L}$, $11.29 \pm 3.47 \mathrm{mmol} / \mathrm{L}, 7.96 \pm 6.04 \mathrm{mg} \%, 189.72 \pm 111.36 \mathrm{mg} / \mathrm{dl}, 179 \pm 43 \mathrm{mg} / \mathrm{dl}, 38.38 \pm 13.77 \mathrm{mg} / \mathrm{dl}$, $102.10 \pm 35.79 \mathrm{mg} / \mathrm{dl}$ and $8.39 \pm 2.61 \mathrm{mg} / \mathrm{dl}$ respectively, on the other hand among the control these were $5.91 \pm 1.13 \mathrm{mmol} / \mathrm{L}, 9.19 \pm 1.95 \mathrm{mmol} / \mathrm{L}, 5.93 \pm 1.01 \mathrm{mg} \%, 200 \pm 104.49 \mathrm{mg} / \mathrm{dl}, \quad 183 \pm 42.25 \mathrm{mg} / \mathrm{dl}$, $38.14 \pm 5.52 \mathrm{mg} / \mathrm{dl}, 110 \pm 33.23 \mathrm{mg} / \mathrm{dl}$ and $5.14 \pm .84 \mathrm{mg} / \mathrm{dl}$ respectively.
\end{abstract}

Key Words: Type 2 D. M, Hypertension, and Uric Acid.

\section{Introduction}

Diabetes mellitus is a clinical syndrome which is characterized by persistent hyperglycaemia due to an absolute or a relative efficiency of insulin. It may be associated with a number of complications which include macro and micro vascular diseases. Uric acid (UA) is the end product of the purine metabolism. The association between the blood

glucose and the serum uric acid levels has been known for quite some time. ${ }^{1}$ A positive association between the serum uric acid levels and the development of type 2 diabetes mellitus (T2DM) has been reported. ${ }^{2}$ In individuals with an impaired glucose tolerance, an elevated Serum Uric Acid (SUA) level was found to increase the risk for

\footnotetext{
$1 *$ Dr. Roksana Yeasmin, Associate Professor of Biochemistry, Ibrahim Medical College, Dhaka

2Dr. M. A. Muttalib, Professor of Biochemistry, BIRDEM, Dhaka

${ }^{3}$ Dr. Nazneen Sultana, Assistant Professor of Biochemistry, Bangladesh Medical College, Dhaka

${ }^{4}$ Dr. Md. Jamil Hasan Karami, Associate Professor, Dept of Statistics, Dhaka University

5Dr. Ayatunnessa, Associate Professor, Laboratory Medicine, BIRDEM

${ }^{6}$ Dr. Fahmida Akhter Maruf, Lecturer of Microbiology, Northern International Medical College

*Corresponding Author
}

Date of submission: 30.10 .2017 , Date of acceptance: 03.02.2018

AKMMC J 2018; 9(2) : 96-101 
developing T2-DM. ${ }^{3}$ Although uricacid can act as an antioxidant, excess serum accumulation is often associated with cardiovascular disease. It is not known whether this is causative (e.g., by acting as a prooxidant) or a protective reaction taking advantage of urate's antioxidant properties. The same may account for the putative role of uric acid in the etiology of strokeUric acid can act as a oxidant and it may thus be a marker of oxidative stress, but it may also have a therapeutic role as an antioxidant ${ }^{4}$. Urate, the soluble form of uric acid, can scavenge the superoxide and the hydroxyl radicals and it can chelate the transition metals. ${ }^{5}$ Hyperuricaemia has been also added to the set of metabolic abnormalities which are associated with insulin resistance and/or hyperinsulinaemia in the metabolic syndrome. ${ }^{6}$ While an increase in the uric acid levels in prediabetes and diabetes was demonstrated by some studies, a declining trend of the serum uric acid levels with increasing blood glucose levels was observed by other research workers. ${ }^{7}$ Hypouricaemia has also been implicated in the development of diabeticnephropathy. ${ }^{8}$ Although some studies have demonstrated the role of UA in the progression of prediabetes to diabetes,conflicting data exist about the uric acid levels in T2DM, which are associated with risk factors and complications. ${ }^{9,10}$ Thus, the role of UA in the pathogenesis and the development of the diabetic complications is controversial. Therefore, the present study was designed to look for any association of serum uric acid with hypertension in T2DM, taking into consideration the relevant clinical, biochemical and the anthropometric data.

\section{Materials \& Methods}

A case control study was conducted on 110 patients with known type 2 male diabetics and on 100 healthy male controlsthat were in the age group of 30-70 years at BIRDEM outpatient department from the period of 1st June 2015 to January 2016 and controls were collected from healthy working men of BIRDEM. All the data were collected in a prescribed proforma andthey were compiled. The questionnaire contained questions regarding the duration of diabetes, the family history of diabetes, the dietary history and the history of hypertension, smoking, alcohol drinking, fast food habit etc.
Inclusion criteria: Individual having history of diabetes and taking treatment with either oral antidiabetic drugs orinsulin were considered to have diabetes.

Exclusion criteria: Individual having history of gout and cardio-vascular or renal diseases and those who were ondrugs (other than antidiabetics) that could alter the blood glucose levels were excluded from the study. The controls were non-diabetic.

The patients who gave a history of hypertension and were on antihypertensive treatment or whose blood pressurewas more than or equal to $140 / 90 \mathrm{~mm}$ of $\mathrm{Hg}$ were considered to have hypertension. The height and the weight of cases andthe controls were measured. The body mass index (BMI) was calculated. The waist/hip ratio $(\mathrm{W} / \mathrm{H}$ ratio) was alsocalculated. All the patients were asked to fast overnight for a period of minimum 10 hours. The blood samples which were takenfor analysis were obtained from the antecubital vein. The analysis of plasma glucose was done by the glucoseoxidase method, while the serum uric acid, cholesterol and triglycerides were evaluated by enzymatic methods. Thesetests were performed on a Roche cobas c-311 biochemical analyser. The statistical analysis was done by the unpairedtwo tailed' $t$ ' test and the Pearson's correlation coefficient by using online calculator. The data were presented asmean with $\mathrm{SD}$. The statistical significance was kept as a $\mathrm{P}$ value of $<0.05$.

\section{Results}

Table 1: Distributions of study population according to age

\begin{tabular}{ccc}
\hline $\begin{array}{c}\text { Age } \\
\text { (years) }\end{array}$ & $\begin{array}{c}\text { Case (Type-2DM) } \\
\mathbf{n = 1 1 0}\end{array}$ & $\begin{array}{c}\text { Control (Healthy } \\
\text { Individual) } \\
\mathbf{n = 1 0 0}\end{array}$ \\
\hline $30-40$ & 16 & 40 \\
$41-50$ & 39 & 33 \\
$51-60$ & 36 & 21 \\
$61-70$ & 19 & 6 \\
Total & 110 & 100 \\
\hline
\end{tabular}


Table 1 shows the distributions of study population according to age and it indicates that 41-50 years study subjects more in Type-2 DM (39) whereas in control $30-40$ years study subjects are more (40).

Table 2: Different range of uric acid levels and their distributions in study subjects

\begin{tabular}{ccc}
\hline $\begin{array}{c}\text { Uric acid } \\
(\mathbf{m g} / \mathbf{d l})\end{array}$ & $\begin{array}{c}\text { Case (Type-2DM) } \\
\mathbf{n = 1 1 0}\end{array}$ & $\begin{array}{c}\text { Control (Healthy } \\
\text { Individual) } \\
\mathbf{n = 1 0 0}\end{array}$ \\
\hline $3.5-6.4$ & 28 & 94 \\
$6.5-9.4$ & 48 & 6 \\
$9.5-12.4$ & 26 & 0 \\
$\geq 12.5$ & 8 & 0 \\
Total & 110 & 100 \\
\hline
\end{tabular}

Table 2 shows the different range of uric acid levels and their distributions in study subjects. It shows that uric acid level ranges from 6.5-9.4 mg/dl distribution more in cases (type -2 male DM) and it was 48 study subjects whereas in control it was 6 study subjectsand in control more study subjects uric acid ranges from 3.5-6.4 mg/dl and it was 94 study subjects.

Table 3: Comparison of different characteristics and biochemical parameters of study subjects

\begin{tabular}{lccc}
\hline Variables & $\begin{array}{c}\text { Case (Type-2 D M) } \\
\mathbf{n}=\mathbf{1 1 0} \\
\text { Mean } \pm \text { SD }\end{array}$ & $\begin{array}{c}\text { Control (Healthy } \\
\text { individual) } \mathbf{n}=\mathbf{1 0 0} \\
\text { Mean } \pm \text { SD }\end{array}$ & P value \\
\hline Age (years) & $51.83 \pm 9.911$ & $44.81 \pm 9.66$ & .000 \\
Duration of diabetes (years) & $6.87 \pm 5.54$ & 00 & .000 \\
Body mass index (kg/m2) & $25.43 \pm 3.19$ & $24.96 \pm 3.02$ & .274 \\
Exercise time (hours) & $1.94 \pm .831$ & $1.12 \pm .327$ & .000 \\
Waist (cm) & $94 \pm 7.06$ & $90.95 \pm 9.51$ & \\
Hip (cm) & $102 \pm 6.19$ & $98.48 \pm 8.24$ & \\
Waist: Hip & $.92 \pm .03$ & $.91 \pm .03$ & .035 \\
Systolic BP (mm of Hg) & $140 \pm 6.75$ & $130 \pm 1.28$ & .002 \\
Diastolic BP (mm of Hg) & $90 \pm 2.41$ & $80 \pm 6.18$ & .000 \\
Fasting blood sugar (mmol/l) & $8.19 \pm 2.48$ & $5.91 \pm 1.13$ & .025 \\
After break fast (ABF) (mmol/l) & $11.29 \pm 3.47$ & $9.19 \pm 1.95$ & .033 \\
HBA1C (mg\%) & $7.96 \pm 6.04$ & $5.93 \pm 1.01$ & .026 \\
TG (mg/dl) & $189.72 \pm 111.36$ & $200 \pm 104.49$ & .468 \\
Cholesterol (mg/dl) & $179 \pm 43$ & $183 \pm 42.25$ & .495 \\
HDL-C (mg/dl) & $38.38 \pm 13.77$ & $38.14 \pm 5.52$ & .870 \\
LDL-C (mg/dl) & $102.10 \pm 35.79$ & $110 \pm 33.23$ & .088 \\
Uric acid (mg/dl) & $8.39 \pm 2.61$ & $5.14 \pm .84$ & .000 \\
\hline & & & \\
\hline
\end{tabular}

Table 3 shows Comparison of different characteristics and biochemical parameters of study subjects. It shows that there were significant differences in mean of age, duration of DM, exercise time, waist hip ratio, systolic blood pressure and diastolic blood pressure within case and control but no significant differences of mean BMI was found between and control. The mean age, duration of DM, exercise time, waist hip ratio, systolic blood pressure and diastolic blood pressure and BMI were $(51.83 \pm 9.911$ years, $6.87 \pm 5.54$ years, $1.94 \pm .831$ hours, $.92 \pm .03,140 \pm 6.75 \mathrm{~mm}$ of $\mathrm{Hg}, 90 \pm 2.41$ $\mathrm{mm}$ of $\mathrm{Hg}$ and $25.43 \pm 3.19 \mathrm{Kg} / \mathrm{m}^{2}$ respectively), where as in controls these were $(44.81 \pm 9.66 \mathrm{yrs}, 00$ years, $1.12 \pm .327$ hours, $.91 \pm .03,130 \pm 1.28 \mathrm{~mm}$ of $\mathrm{Hg}, 80 \pm 6.18 \mathrm{~mm}$ of $\mathrm{Hg}$ and $24.96 \pm 3.02 \mathrm{Kg} / \mathrm{m}^{2}$ respectively). This table also shows that significant differences in mean of $\mathrm{FBS}, \mathrm{ABF}, \mathrm{HbA}_{1 \mathrm{C}}$ and $\mathrm{S}$. Uric acid between case and control, but there was no significant differences of mean TG, Cholesterol, HDL and LDL. The mean of FBS, ABF, $\mathrm{HbA}_{1 \mathrm{C}}$ and S. Uric acid among the cases were $(8.19 \pm 2.48$ $\mathrm{mmol} / \mathrm{L}, 11.29 \pm 3.47 \mathrm{mmol} / \mathrm{L}, 7.96 \pm 6.04 \mathrm{mg} \%$, $189.72 \pm 111.36 \mathrm{mg} / \mathrm{dl}, \quad 179 \pm 43 \mathrm{mg} / \mathrm{dl}$, $38.38 \pm 13.77 \mathrm{mg} / \mathrm{dl}, 102.10 \pm 35.79 \mathrm{mg} / \mathrm{dl}$ and $8.39 \pm 2.61 \mathrm{mg} / \mathrm{dl}$ respectively, on the other hand among the control these were $5.91 \pm 1.13 \mathrm{mmol} / \mathrm{L}$, $9.19 \pm 1.95 \mathrm{mmol} / \mathrm{L}, 5.93 \pm 1.01 \mathrm{mg} \%, 200 \pm 104.49$ $\mathrm{mg} / \mathrm{dl}, \quad 183 \pm 42.25 \mathrm{mg} / \mathrm{dl}, \quad 38.14 \pm 5.52 \mathrm{mg} / \mathrm{dl}$, $110 \pm 33.23 \mathrm{mg} / \mathrm{dl}$ and $5.14 \pm .84 \mathrm{mg} / \mathrm{dl}$ respectively.

Table 4: serum uric acid level associated with hypertension in $\mathrm{T} 2 \mathrm{DM}$ as Mean $\pm \mathrm{SD}$

\begin{tabular}{lccc}
\hline Variable & $\begin{array}{c}\text { Case (Type-2 D M) } \\
\text { Hypertensive } \\
\text { Mean } \pm \text { SD }\end{array}$ & $\begin{array}{c}\text { Case(Type-2 DM ) } \\
\text { NonHypertensive } \\
\text { Mean } \pm \text { SD }\end{array}$ & P value \\
\hline $\begin{array}{c}\text { Uric acid } \\
\text { (mg/dl) }\end{array}$ & $7 \pm 1.61$ & $5 \pm .25$ & .002 \\
\hline Significant $p$ value $<.001)$ & & \\
\hline
\end{tabular}

Table 4 shows that mean serum uric acid level in type-2DM hypertensive study subjects is significantly increased than non-hypertensive type$2 \mathrm{DM}$ and it was $7 \pm 1.61 \mathrm{mg} / \mathrm{dl}$ and $5 \pm .25 \mathrm{mg} / \mathrm{dl}$ respectively. 
Table 5: Correlations of serum uric acid level associated with duration of DM and BP

\begin{tabular}{cccc}
\hline & $\begin{array}{c}\text { Duration of } \\
\text { Diabetes } \\
\mathbf{r}=.416^{* *}\end{array}$ & Systolic BP & Diastolic BP \\
\cline { 2 - 4 } & $\mathrm{p}=.000$ & $\mathrm{r}=.056$ & $\mathrm{r}=.141$ \\
$\mathrm{p}=.418$ & $\mathrm{p}=.041$ \\
\hline
\end{tabular}

Table 4 shows the correlations of Serum uric acid with Blood pressure and duration of DM. It shows that serum uric acid is significantly correlated with duration of DM. It also shows that serum uric acid is positively correlated with diastolic blood pressure where $r=.141$ and significance level was .041 but in systolic BP it was not significantly correlated.

\section{Discussion}

Uric acid is the final product of the purine metabolism in humans. The 2 final reactions in its production which catalyze the conversion of hypoxanthine to xanthine and the latter to uric acid are catalyzed by the enzyme xanthine oxidoreductase, which may attain 2 inter-convertible forms, namely xanthine dehydrogenase or xanthine oxidase. The latter uses molecular oxygen as an electron acceptor and it generates a superoxide anion and other Reactive Oxygen Species (ROS), thus favoring an antioxidant - prooxidant urate redox shuttle. ${ }^{10,11} \mathrm{UA}$ is also a physiological free radical scavenger and one of the major contributors of the plasma antioxidant capacity ${ }^{12}$. Thus, UA plays a dual role, both as a prooxidant and as an antioxidant. ${ }^{13,14} \mathrm{~T} 2 \mathrm{DM}$ is associated with oxidative stressand increased free radical formation. ${ }^{15}$ While on one hand, hyperglycaemia generates free radicals, on the other hand, it also impairs the endogenous antioxidant defense system. ${ }^{16}$ Under the condition of increased oxidativestress, there occurs the depletion of the local antioxidants, which causes a reduction in the antioxidant status of thebody. ${ }^{17}$ Studies have reported the association of hypouricaemia with T2DM. ${ }^{18,19}$ A positive relationship has been described between glycosuria and uricosuria. ${ }^{20}$ Further, a higher degree of hyperglycaemia was observed to be associated with an increased rate of uric acid excretion and lowering of the plasma uric acid levels. ${ }^{20}$ Hypouricaemia andrisk factor for type 2 diabetes mellitus. Diabetes
Carethe tubular transport of uric acid have been thoroughly reviewed. ${ }^{21}$ An increased urate clearance due to increased glomerular hyperfiltration which is aresult of an abnormality in the tubular urate handling hasbeen reported. ${ }^{22}$ The Serum uric acid levels were foundto be higher in males than in females ${ }^{23}$. We reported asimilar finding in our study. The findings of the BMI, age, duration of DM andthe waist hip ratio in the diabetic males in ourstudy were in accordance with the findings of others. ${ }^{24,25}$ Our study reported a significant differences in mean of diastolic and systolic blood pressure in type-2DM and healthy individual and it was $(90 \pm 8.41,80 \pm 6.18) \mathrm{mm}$ of $\mathrm{Hg}$ and $140 \pm 16.75, \quad 130 \pm 11.28 \mathrm{~mm}$ of Hgrespectively and $\mathrm{p}$ value was.000 and .002 which were in agreement with the findings of otherstudies. ${ }^{26}$ While the incidence of hypercholesterolaemiaand hypertension and a family history of diabetes weremore in the female diabetics the incidences ofhypertriglyceridaemia, smoking, and alcohol drinkingwere more in the male diabetic patients. These findingswere in corroboration with those of other studies. ${ }^{24}$ According to study by Johnson and colleagues; they havereported a positive association of hyperuricaemia withhypertension in T2DM with complications. ${ }^{27}$ In contrast, a statistically significant decrease in the serum uric acidlevels in the hypertensive diabetics (both males andfemales) in comparison with the non-hypertensivediabetics, was observed in our study. As a increase in theserum uric acid levels was seen with high plasma glucoselevels in diabetes which was complicated with hypertension, as was observed in our study, may be of pathogenic significance. Several factors are known to alter the serum uric acid levels in T2DM.

\section{Conclusion}

Hyperglycemia with long term duration of type 2 diabetes mellitus is major risk factor for macro and micro vascular complications which causes retinopathy, neuropathy and cardiovascular disease. Many factors like family history of diabetes, life style, obesity, hypertension and mixed diet are contributing in type 2 diabetic patients. In present study the serum uric acid and blood pressure were measured and evaluated and there is a significant 
difference in mean uric acid level in type -2 DM hypertensive and significant correlation of uric acid level with diastolic blood pressure was found.

\section{Conflict of interest: no.}

\section{Refrences}

1. Herman JB, Medalie JH, Goldbourt U. Diabetes, prediabetes and uricaemia. Diabetologia. 1976; 12(1): 47-52.

2. Kodama S, Saito K, Yachi Y, Asumi M, Sugawara A, Totsuka $\mathrm{K}$, et al. The association between serum uricacid and the develop-ment of type 2 diabetes mellitus. A meta-Analysis. Diabetes Care. 2009; 32(9): 1737-42.

3. Caroline K, Denise V, Simerjot K, Elizabeth B. The serum uric acid levels improve the prediction of theincident type 2 diabetes in individuals with impaired fasting glucose levels. The Rancho Bernardo Study. Diabetes Care. 2009; 32(7): 1272-73.

4. Patterson RA, Horsley E TM, Leake DS. The prooxidant and the anti-oxidant properties of the human serumultrafiltrates towards LDL: the important role of uric acid. J Lipid Res. 2003; 44(3): 512-21.

5. Ames BN, Cathcart R, Schwiers E, Hochstein $P$. Uric acid provides an antioxidant defence mechanism inhumans against oxidants and radicals which cause aging and cancer: a hypothesis. Proc Natl Acad Sci USA, 1981; 78: 6858-62

6. Nakagawa $\mathrm{T}, \mathrm{Hu} \mathrm{H}$, Zharikov $\mathrm{S}$, Tuttle KR, Short RA, Glushakova O, et al. A causal role of uric acid in thefructose- induced metabolic syndrome. Am. J. Physiol. Renal. Physiol. 2005; 290: F 625-31.

7. Nan H, Dong Y, Gao W, Tuomilehto J, Qiao Q. Diabetes, which was associated with a low general Chinese population. Diabetes Res and Clin Pract. 2007; 76: 68-74.

8. Shichiri, M, Iwamoto H, Marumo F. Diabetic hypouricemia as an indi-cator of clinical nephropathy. Am J Nephrol. 1990; 10(2): 115-22.
9. Dehghan A, van Hoek M, Sijbrands JG, Hofman A, Witteman JCM. High levels of serum uric acid as a novelrisk factor for type 2 diabetes mellitus. Diabetes Care

10. Hayden MR, Tyagi SC. Uric acid: A new look at an old risk marker for cardiovascular disease, metabolic syndrome, and type 2 diabetes mellitus:

11. The urate redox shuttle. Nutr and Metab (Lond). 2004, 1:10. Becker BF, Reinholz N, Leipert B, Raschke P, Permanetter B, Ger-lach E. The roles of uric acid as an endogenous radical scavenger and an antioxidant. Chest $\mathrm{J}$. 1991; 100(3): 176S-181S.

12. Javier Nieto FA, Iribarren C, Gross D, Comstock $\mathrm{W}$, Cutler G. The uric acid and the serum antioxidant capacity: a reaction to atherosclerosis? Atherosclerosis. 2000; 148: 131-39.

13. Bagnati M, Cristina $\mathrm{P}$, Cristiana CAU, Roberta B, Emanuele A, Giorgio B. When and why a water-soluble antioxidant becomes pro-oxidant during a copperinduced, low-density lipoprotein oxidation: a study which was done by using uric acid. Biochem J. 1999; 340: 143-52.

14. Strasak AM, Rapp K, Hilbe W, Oberaigner W, Ruttmann E, Con-cin $\mathrm{H}$. The role of serum uric acid as an antioxidant which protects against cancer: a prospective study in more than 28000 old Austrian women. Ann Oncol 2007; 18: 1893-97.

15. Maritim AC, Sanders RA, Watkins JB. Diabetes, oxidative stress, and antioxidants: a review. J Biochem Mol Toxicol; 2003; 17: 24-38.

16. Ceriello A. The total radical-trapping antioxidant parameter in NIDDM patients. Diabetes Care. 1997; 20: 2.

17. Bonnefont-Rousselot D and associates. Consequences of the di abetic status on the oxidant/antioxidant balance. Diabetes Metab (Paris). 2000; 26: 163-76 
18. Ishihara $\mathrm{M}$, Shinoda $\mathrm{T}$, Aizawa $\mathrm{T}$ et al., Hypouricemia in NIDDM pa-tients. Diabetes Care. 1998; 11:10

19. Kanuchi M. Hypouricemia in hospitalized diabetics patients. J. Nara. Med. Ass. 1997; $48,268-72$

20. Bonsnes RW, Dana ES. On the increased uric acid clearance follow-ing the intravenous infusion of a hypertonic glucose solution. J Clin Invest.1946; 25: 386- 88

21. Martín NE, García NV. Hypouricemia and the tubular transport of uric acid. Nefrologia. 2011; 31(1): 44-50.

22. Shichiri M, Iwamoto $H$, Shiigai T. Diabetic renal hypouricemia. Arch Intern Med 1987: 147(2): 225-28.

23. Gephardt C, Thomas J, Charles F. The uric acid values as related to the sex and age. J Am Med Assoc. 1964; 189(13): 136-37
24. Nan H, Pang Z, Wang S, Gao W. Serum uric acid, plasma glucose and diabetes. Diabetes Vasc Dis Re. 2010; 7(1): 40-46

25. Schmidt M. I., Duncan B, Canani H, Karohi C, Chambers L. The association of the waist-hip ratio with diabetes mellitus. Diabetes Care.1992; 15(7): 912-14

26. Cook DG, Shaper AG, Thelle DS, Whitehead TP. Serum uric acid, serum glucose and diabetes: relationships in a population study. Postgrad Med J. 1986; 62: 1001-06

27. Johnson RJ, Kang DH, Feig D, Kivlighn S, Kanellis J, Watanabe S, Tuttle KR, RodriguezIturbe B, Herrera- Acosta J, Mazzali M. Is there a pathogenetic role for uric acid in hypertension and cardiovascular and renal diseases? Hypertension. 2003; 41(6): 1183-90 